\title{
Association between Level of Interleukin 10 and Biochemical Tests in Some Iraqi Diabetic Patients
}

\author{
Hussein Thumad Alkaisey \\ MiddleTechnicalUniversity, College of health and medical techbology, Baghdad, Iraq. \\ drnihadkhalawe@gmail.com.
}

Submission date:- 16/5/2018 Acceptance date:- 3/6/2018 Publication date:- 2/12/2018

Keywords: Diabetes mellitus (DM), biochemical tests, IL10, diabetic Iraqi patients.

\begin{abstract}
Background: Diabetes mellitus (DM) can be defined as clinical syndrome or disturbance of carbohydrates metabolism characterized by hyperglycemia ,so diabetes is immunes dependent disease in which the changed patterns of expression of cytokine, anti-inflammatory factors as interleukin-10 play an essential role in many infections. As well as, IL-10 has important main inhibitory cytokine against the work of inflammatory cytokines, as interleukin 12. Therefore, this study was designed to evaluate the serum level of interleukin 10 and biochemical tests in Iraqi diabetic patients and controls [fasting blood sugar (FBS);urea; creatinine; triglyceride (T.G); total cholesterol; low density lipoprotein (LDL); high density lipoprotein (HDL); as well as very low density lipoprotein (VLDL). Interleukin 10 (IL10) serum level was measure by ELISA kit for both groups. This study was conducted from January-April 2018 in Specialist Center for Endocrinology and Diabetes in Baghdad government and correlates between IL10 concentration and biochemical tests in diabetic Iraqi patients. Results of current study showed a high incidence of both diabetes types ( I\&II) of in the age group $2(41-60)$ years old as $(\mathrm{NO} .=13,11)$ and percentage as $(17.3,14.7)$ \%respectively, so, female $(\mathrm{NO}=18,14)$ and percentage as $(20.0,18.7)$ \% respectively had a higher prevalence of diabetes than male $[12.0$ ,12.0) and high incidence of diabetes in female[20.0, 18.7] \% more than male. Additionally, this study showed that creatinine; urea; F.B.S levels were higher $(26.7 ; 4.0,28.0] \%$ in diabetic type I than diabetic type II as $(20,0,24.0] \%$ and compare to control as [17.3, 14.7 and 0)\%.and increased levels of lipid profile as ( Total Cholesterol; triglyceride T.G ; LDL ; HDL ; and VLDL ) in diabetic type I as $(10 ; 16 ; 12 ; 1 ; 20) \%$ than in diabetic type II; as well as; IL-10 serum level was abnormal with creatinine levels in 35 patients as percentage $46.7 \%$; also IL-10 serum level was abnormal with fasting blood sugar for 39 patients as percentage $52.0 \%$; whilst only 3 patients as $4.0 \%$ with abnormal urea levels as well as IL-10 level was abnormal with levels lipid profile as ( Triglyceride T.G; Total Cholesterol; LDL, HDL and VLDL)as ( $1.3 ; 25.3 ; 38.7 ; 26.7$ and 22.7$) \%$ respectively. Based on these facts, it may be concluded that abnormal serum levels of IL-10 with biochemical tests can be considered as risk factors of diabetes.
\end{abstract}

\section{1- Introduction:}

Diabetes mellitus (DM), is a collection of the metabolic disturbance in that, there are elevated levels of blood glucose in long periods[1].Symptoms of diabetes include : repeated urination , increased blood glucose level ; as well as; increased both hunger and thirst ,Untreated diabetes can cause many problems such as ketoacidosis; neuropathy; hyperosmolar hyperglycemic state; retinopathy; nephropathy and cardiovascular complications [2].

Two main kinds of diabetes mellitus, as type I diabetes which is an organ-specific autoimmune disease that characterized by invasion of the auto-reactive T- cell (T-lymphocyte) to the cells of the Langerhans islets that secretes insulin and produce autoantibodies versus pancreas antigen( $\mathrm{Ag}$ ) [3]. While other type is type II diabetes which characterized by the insulin resistance, that may combine with relatively reducing insulin secretion[4]. The third type of diabetes is called gestational D.M that is a transitory condition that occurs in pregnant women (3- 20\%) during pregnancy period. This gestational diabetes may increase the risk of development of diabetes for both fetus and mother depending on many risk factors. Among these 3 kinds of the diabetes, the more common was type 2 diabetes according to $\mathrm{WHO}, 2017$. Therefore, early detection and preventive action are required, whereas, symptoms don't appear before damage is done, The patients should regularly checked by ophthalmologist or an optometrist [5],[6]. 
The functions of both types of immune system depend on large particles such as antibodies and interleukins, so, in immune deficiency or autoimmune diseases, can produce important main interleukins by helper CD4 T lymphocytes; macrophages; endothelial cells and monocytes. They enhance the differentiation and development of both B-cell, T-cell lymphocytes and hematopoietic cells[7].

The type of Interleukin as IL-10 has the ability to inhibit synthesis of pro-inflammatory cytokines such as both interleukin 2 and IL-3 ;GM-CSF; IFN- $\gamma$ and TNF $\alpha$; as well asit exhibits a strong capability for suppression of antigen-presenting capacity of (APC) antigen presenting cells. Moreover, mast cells and stimulating maturation of B cell and producing antibody; also; stimulatory towards the certain T-cells (Th2). So the produced IL-10 by the mast cells, counteracts the effecting inflammatory [8].

\section{2-Materials and methods:}

Sample collection: Fifty diabetic patients and twenty-five healthy individuals [control] from Specialist Center for Endocrinology and Diabetes and alternatives Unit/College of Medical \& Health Technology, in Baghdad city were enrolled in this study. The blood collected from both patients \&healthy ( control) groups, and was left for 30 minutes to clot at temperature laboratory. Then, the sample were discarded using the device Centrifuge at speed 2500 RPM for 10 minutes. Then, serum was collected by Micropipte, and kept it at a temperature $-20{ }^{\circ} \mathrm{C}$ to be later used. Their ages were ranged between $8-65$ years.

Biochemical tests: Automatic chemical analyzer was used to estimate the biochemical tests [fasting blood sugar (FB) by glucose oxidase method, ; creatinine; urea; were determined by enzymatic colorimetric methods . as well as total cholesterol; triglycerides (T.G); LDL ; HDL and VLDL were measured by the enzymatic method using Biomaghreb, Tunisia Kits.

Interleukin (IL10) serum level: Enzyme-linked immunosorbent assay (Elisa ) kit (BioLegend, Netherlands). was used for measurement level of IL10 in serum quantitatively.

Statistical analysis: Chi-square was used to detect the significance differences $(\mathrm{p}<0.05)$ among the variables of our study by SPSS ver.18.0.

\section{3-Results:}

Table (1): Age and gender distribution of diabetic patients .

\begin{tabular}{|c|c|c|c|c|c|c|}
\hline \multirow{2}{*}{$\begin{array}{c}\text { Study } \\
\text { Groups }\end{array}$} & \multicolumn{3}{|c|}{ Age Groups(years) } & \multicolumn{2}{|c|}{ Genders } & \multirow{2}{*}{$\begin{array}{l}\text { Total } \\
\text { (No.,\%) }\end{array}$} \\
\hline & $\begin{array}{l}\text { group } 1 \\
(9-40) \\
{[\text { No., \%) }}\end{array}$ & $\begin{array}{c}\text { group } 2 \\
(41-60) \\
{[\text { No., \%) }}\end{array}$ & $\begin{array}{c}\text { group3 } \\
(\geq 61) \\
{[\text { No., \%) }}\end{array}$ & $\begin{array}{l}\text { Female } \\
\text { (No.,\%] }\end{array}$ & $\begin{array}{c}\text { Male } \\
\text { (No.,\%) }\end{array}$ & \\
\hline \multirow[t]{2}{*}{ DM-I } & 8 & 13 & 6 & 18 & 9 & 27 \\
\hline & $10.7 \%$ & $17.3 \%$ & $8.0 \%$ & $24.0 \%$ & $12.0 \%$ & $36.0 \%$ \\
\hline \multirow[t]{2}{*}{ DM-II } & 2 & 11 & 10 & 14 & 9 & 23 \\
\hline & $2.7 \%$ & $14.7 \%$ & $13.3 \%$ & $18.7 \%$ & $12.0 \%$ & $30.7 \%$ \\
\hline \multirow{2}{*}{$\begin{array}{l}\text { Control } \\
\text { (Healthy) }\end{array}$} & 14 & 10 & 1 & 17 & 8 & 25 \\
\hline & $18.7 \%$ & $13.3 \%$ & $1.3 \%$ & $22.7 \%$ & $10.7 \%$ & $33.3 \%$ \\
\hline \multirow[t]{2}{*}{ Total } & 24 & 34 & 17 & 49 & 26 & 75 \\
\hline & $32.0 \%$ & $45.3 \%$ & $22.7 \%$ & $65.3 \%$ & $34.7 \%$ & $100.0 \%$ \\
\hline \multicolumn{4}{|c|}{$0.002 \mathrm{~S}$} & \multicolumn{3}{|c|}{$0.8 \mathrm{NS}$} \\
\hline
\end{tabular}

Result showed in table (1) a high incidence of both types( I \&II ) of diabetes in the age group 2( 41-60) years old as $(\mathrm{NO} .=13,11)$ and percentage as $(17.3,14.7) \%$ respectively, so incidence of diabetes for both types in the age group 2(41-60) years old as percentage (45.3) \%, followed by both groups ( 3 and 1) as (32 and 22.7] \%respectively( figure $1)$; as well as female $(\mathrm{NO}=18,14)$ and percentage as $(20.0,18.7)$ \%respectively had a higher prevalence of diabetes than male $(12.0,12.0)$ and a high incidence of diabetes in female $(20.0,18.7) \%$ more than male ( figure 2$)$. 


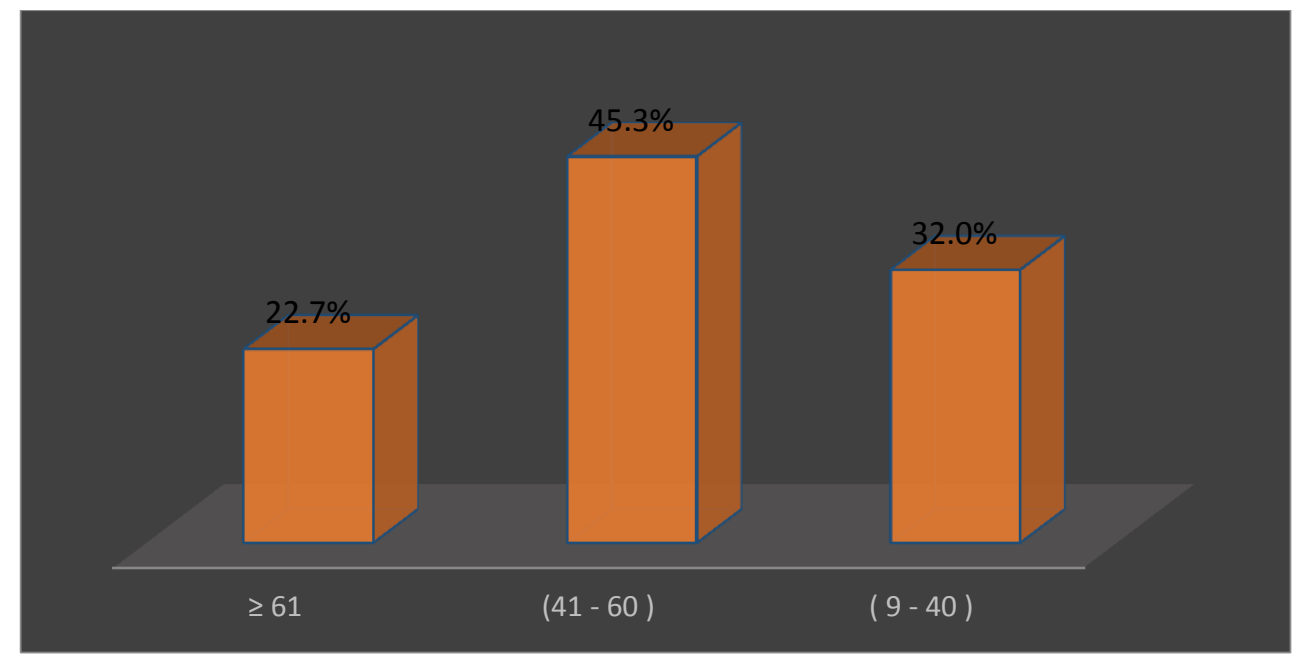

Figure (1): Age distribution of diabetic patient .

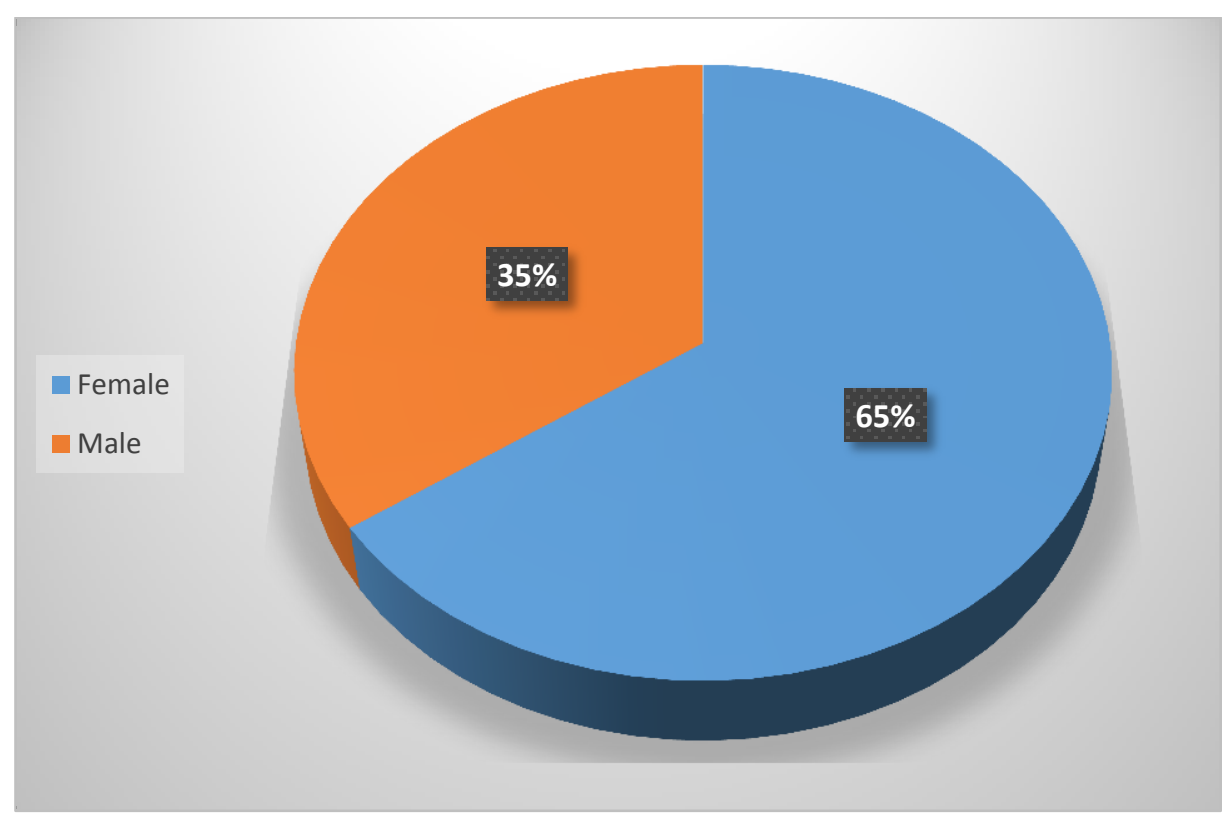

Figure (2): Distribution of diabetic patients according to gender. 
Table (2): Comparison between type of diabetes mellitus and biochemical tests.

\begin{tabular}{|c|c|c|c|c|c|c|}
\hline \multirow{2}{*}{\multicolumn{2}{|c|}{$\begin{array}{c}\text { Biochemical } \\
\text { Tests }\end{array}$}} & \multicolumn{4}{|c|}{ Study Groups } & \multirow{2}{*}{ p.value } \\
\hline & & $\begin{array}{l}\text { DM-I } \\
\text { (No.,\%) }\end{array}$ & $\begin{array}{l}\text { DM-II } \\
\text { (No.,\%) }\end{array}$ & $\begin{array}{c}\text { (non-diabetic)] Healthy } \\
\text { (No.,\%) }\end{array}$ & $\begin{array}{l}\text { Total } \\
\text { (No.,\%) }\end{array}$ & \\
\hline \multirow{6}{*}{$\begin{array}{l}\text { Creatinine } \\
\text { Levels }\end{array}$} & \multirow{2}{*}{ Normal } & 7 & 8 & 12 & 27 & \multirow{6}{*}{$0.2 \mathrm{NS}$} \\
\hline & & $9.3 \%$ & $10.7 \%$ & $16.0 \%$ & $36.0 \%$ & \\
\hline & \multirow{2}{*}{ Abnormal } & 20 & 15 & 13 & 48 & \\
\hline & & $26.7 \%$ & $20.0 \%$ & $17.3 \%$ & $64.0 \%$ & \\
\hline & \multirow{2}{*}{ Total } & 27 & 23 & 25 & 75 & \\
\hline & & $36.0 \%$ & $30.7 \%$ & $33.3 \%$ & $100.0 \%$ & \\
\hline \multirow{6}{*}{ Urea Levels } & \multirow[t]{2}{*}{ Normal } & 24 & 23 & 14 & 61 & \multirow{6}{*}{$\begin{array}{l}0.000 \\
\mathrm{HS}\end{array}$} \\
\hline & & $32.0 \%$ & $30.7 \%$ & $18.7 \%$ & $81.3 \%$ & \\
\hline & Abnormal & 3 & 0 & 11 & 14 & \\
\hline & & $4.0 \%$ & $0.0 \%$ & $14.7 \%$ & $18.7 \%$ & \\
\hline & \multirow{2}{*}{ Total } & 27 & 23 & 25 & 75 & \\
\hline & & $36.0 \%$ & $30.7 \%$ & $33.3 \%$ & $100.0 \%$ & \\
\hline \multirow{6}{*}{$\begin{array}{l}\text { Fasting blood } \\
\text { sugar }\end{array}$} & \multirow[t]{2}{*}{ Normal } & 6 & 5 & 25 & 36 & \multirow{6}{*}{$\begin{array}{l}0.000 \\
\text { HS }\end{array}$} \\
\hline & & $8.0 \%$ & $6.7 \%$ & $33.3 \%$ & $48.0 \%$ & \\
\hline & Abnormal & 21 & 18 & 0 & 39 & \\
\hline & & $28.0 \%$ & $24.0 \%$ & $0.0 \%$ & $52.0 \%$ & \\
\hline & \multirow{2}{*}{ Total } & 27 & 23 & 25 & 75 & \\
\hline & & $36.0 \%$ & $30.7 \%$ & $33.3 \%$ & $100.0 \%$ & \\
\hline
\end{tabular}

The table(2) showed creatinine; urea ; Fasting blood sugar levels were higher $(26.7,4.0,28.0) \%$ in type I diabetic than type II as $(20,0,24.0) \%$ and compare to control as $(17.3,14.7$ and 0$) \%$. 
Table (3):Lipid profile in diabetic \& non diabetic patients

\begin{tabular}{|c|c|c|c|c|c|c|}
\hline \multirow{2}{*}{\multicolumn{2}{|c|}{ Lipids Profile }} & \multicolumn{4}{|c|}{ Study Groups } & \multirow{3}{*}{ p.value } \\
\hline & & $\begin{array}{c}\text { DM-I } \\
\text { (No.,\%) }\end{array}$ & $\begin{array}{c}\text { DM-II } \\
\text { (No.,\%) }\end{array}$ & $\begin{array}{c}\text { Healthy } \\
\text { (non diabetic) } \\
\text { (No.,\%) }\end{array}$ & Total & \\
\hline \multirow{6}{*}{$\begin{array}{l}\text { Total } \\
\text { Cholesterol }\end{array}$} & \multirow{2}{*}{ Normal } & 15 & 15 & 21 & 51 & \\
\hline & & $20.0 \%$ & $20.0 \%$ & $28.0 \%$ & $68.0 \%$ & \multirow{5}{*}{$0.08 \mathrm{NS}$} \\
\hline & \multirow{2}{*}{ Abnormal } & 12 & 8 & 4 & 24 & \\
\hline & & $16.0 \%$ & $10.7 \%$ & $5.3 \%$ & $32.0 \%$ & \\
\hline & \multirow{2}{*}{ Total } & 27 & 23 & 25 & 75 & \\
\hline & & $36.0 \%$ & $30.7 \%$ & $33.3 \%$ & $100.0 \%$ & \\
\hline \multirow{6}{*}{ HDL } & \multirow[t]{2}{*}{ Normal } & 19 & 12 & 24 & 55 & \multirow{6}{*}{$0.003 \mathrm{~S}$} \\
\hline & & $25.3 \%$ & $16.0 \%$ & $32.0 \%$ & $73.3 \%$ & \\
\hline & \multirow[t]{4}{*}{ Abnormal } & 8 & 11 & 1 & 20 & \\
\hline & & $10.7 \%$ & $14.7 \%$ & $1.3 \%$ & $26.7 \%$ & \\
\hline & & 27 & 23 & 25 & 75 & \\
\hline & & $36.0 \%$ & $30.7 \%$ & $33.3 \%$ & $100.0 \%$ & \\
\hline \multirow{6}{*}{ LDL } & \multirow[t]{2}{*}{ Normal } & 26 & 23 & 25 & 74 & \multirow{6}{*}{$0.4 \mathrm{NS}$} \\
\hline & & $34.7 \%$ & $30.7 \%$ & $33.3 \%$ & $98.7 \%$ & \\
\hline & \multirow[t]{4}{*}{ Abnormal } & 1 & 0 & 0 & 1 & \\
\hline & & $1.3 \%$ & $0.0 \%$ & $0.0 \%$ & $1.3 \%$ & \\
\hline & & 27 & 23 & 25 & 75 & \\
\hline & & $36.0 \%$ & $30.7 \%$ & $33.3 \%$ & $100.0 \%$ & \\
\hline \multirow{6}{*}{ VLDL } & \multirow{2}{*}{ Normal } & 18 & 15 & 22 & 55 & \multirow{6}{*}{$0.1 \mathrm{NS}$} \\
\hline & & $24.0 \%$ & $20.0 \%$ & $29.3 \%$ & $73.3 \%$ & \\
\hline & \multirow{4}{*}{ Abnormal } & 9 & 8 & 3 & 20 & \\
\hline & & $12.0 \%$ & $10.7 \%$ & $4.0 \%$ & $26.7 \%$ & \\
\hline & & 27 & 23 & 25 & 75 & \\
\hline & & $36.0 \%$ & $30.7 \%$ & $33.3 \%$ & $100.0 \%$ & \\
\hline \multirow{6}{*}{ T.G } & \multirow{2}{*}{ Normal } & 12 & 9 & 15 & 36 & \multirow{6}{*}{$0.31 \mathrm{NS}$} \\
\hline & & $16.0 \%$ & $12.0 \%$ & $20.0 \%$ & $48.0 \%$ & \\
\hline & \multirow{4}{*}{ Abnormal } & 15 & 14 & 10 & 39 & \\
\hline & & $20.0 \%$ & $18.7 \%$ & $13.3 \%$ & $52.0 \%$ & \\
\hline & & 27 & 23 & 25 & 75 & \\
\hline & & $36.0 \%$ & $30.7 \%$ & $33.3 \%$ & $100.0 \%$ & \\
\hline
\end{tabular}


Results of table (3) showed that increased level of lipid profile (Total Cholesterol; HDL; LDL; VLDL and T.G) in type I as[16; $10,1,12,20) \%$; whilst the levels of them in type II as $(10,14,0,10,18) \%$ respectively compare to control (healthy persons) as $(5,1,0,4,13) \%$.

Table (4): Comparison between 1L-10 levels and biochemical tests in diabetic patients.

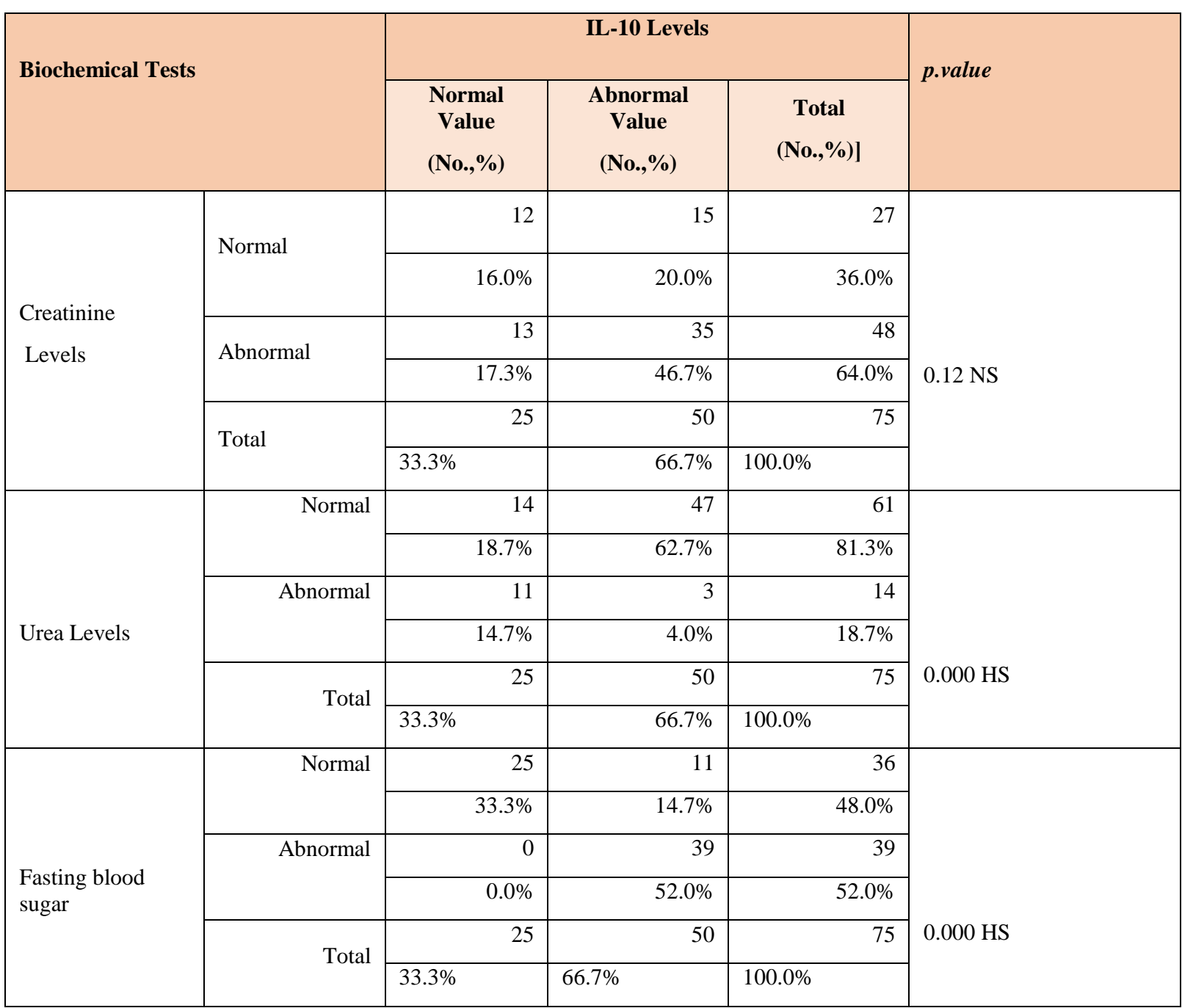

Results in table (4) showed that the IL-10 serum level was abnormal with creatinine levels in 35 patients as percentage $46.7 \%$, also IL-10 serum level was abnormal with fasting blood sugar for 39 patients as percentage $52.0 \%$, whilst only 3 patients as $4.0 \%$ with abnormal urea levels(see figure - 3),Based on this fact, it may be concluded that abnormal serum levels of IL-10 with biochemical test can be considered as a risk factor of diabetes (figure 3). 


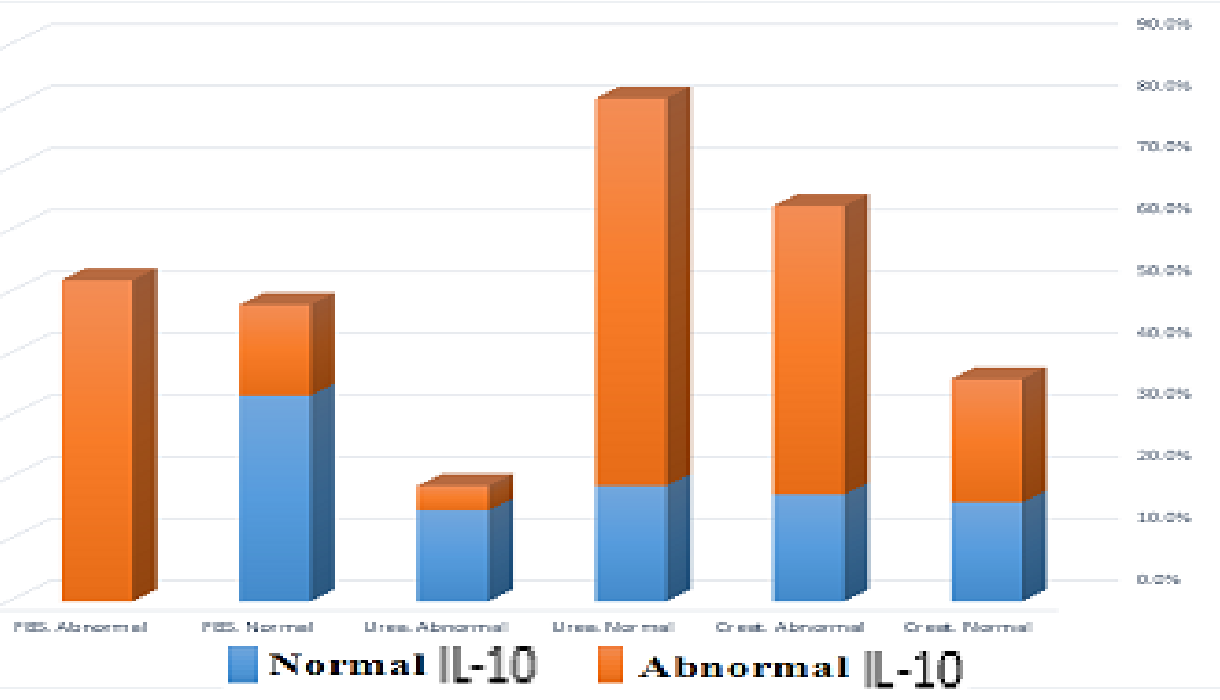

Figure(3): distribution of levels of IL10 \& biochemical tests.

Table (5): Levels of interleukin-10 and lipid profile in diabetic patients.

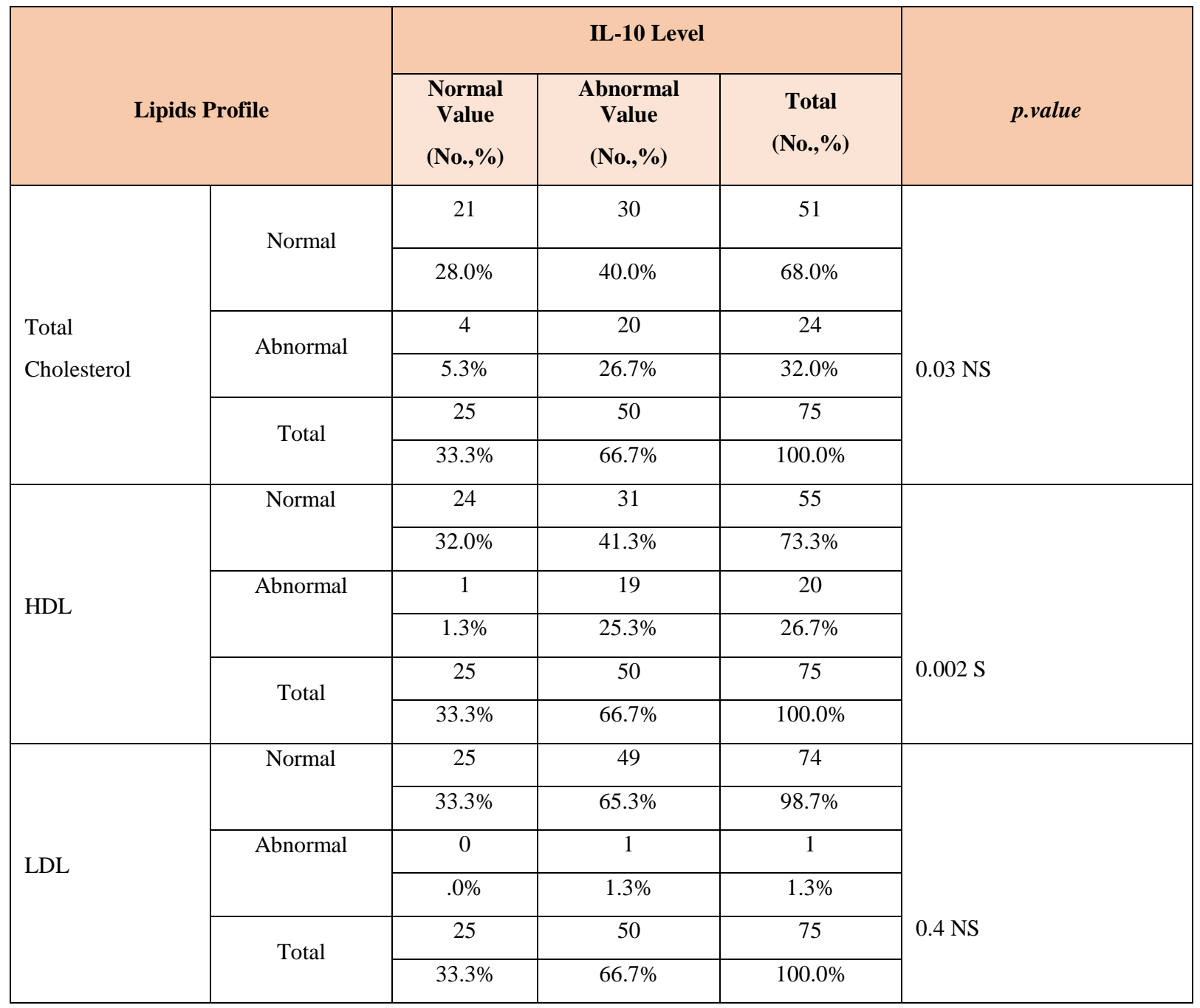




\begin{tabular}{|c|c|c|c|c|c|}
\hline \multirow{6}{*}{ VLDL } & \multirow{2}{*}{ Normal } & 22 & 33 & 55 & \multirow{6}{*}{$0.04 \mathrm{~S}$} \\
\hline & & $29.3 \%$ & $44.0 \%$ & $73.3 \%$ & \\
\hline & \multirow{2}{*}{ Abnormal } & 3 & 17 & 20 & \\
\hline & & $4.0 \%$ & $22.7 \%$ & $26.7 \%$ & \\
\hline & \multirow{2}{*}{ Total } & 25 & 50 & 75 & \\
\hline & & $33.3 \%$ & $66.7 \%$ & $100.0 \%$ & \\
\hline \multirow{6}{*}{ T.G } & \multirow{2}{*}{ Normal } & 15 & 21 & 36 & \multirow{6}{*}{$0.14 \mathrm{NS}$} \\
\hline & & $20.0 \%$ & $28.0 \%$ & $48.0 \%$ & \\
\hline & \multirow{2}{*}{ Abnormal } & 10 & 29 & 39 & \\
\hline & & $13.3 \%$ & $38.7 \%$ & $52.0 \%$ & \\
\hline & \multirow{2}{*}{ Total } & 25 & 50 & 75 & \\
\hline & & $33.3 \%$ & $66.7 \%$ & $100.0 \%$ & \\
\hline
\end{tabular}

Results in table (5) showed that the IL-10 serum level was abnormal with levels of lipid profile; Total cholesterol; HDL; LDL; VLDL and triglyceride as $(26.7 ; 25.3 ; 1.3 ; 22.7$ and 38.7$) \%$ respectively (figure 4$)$.

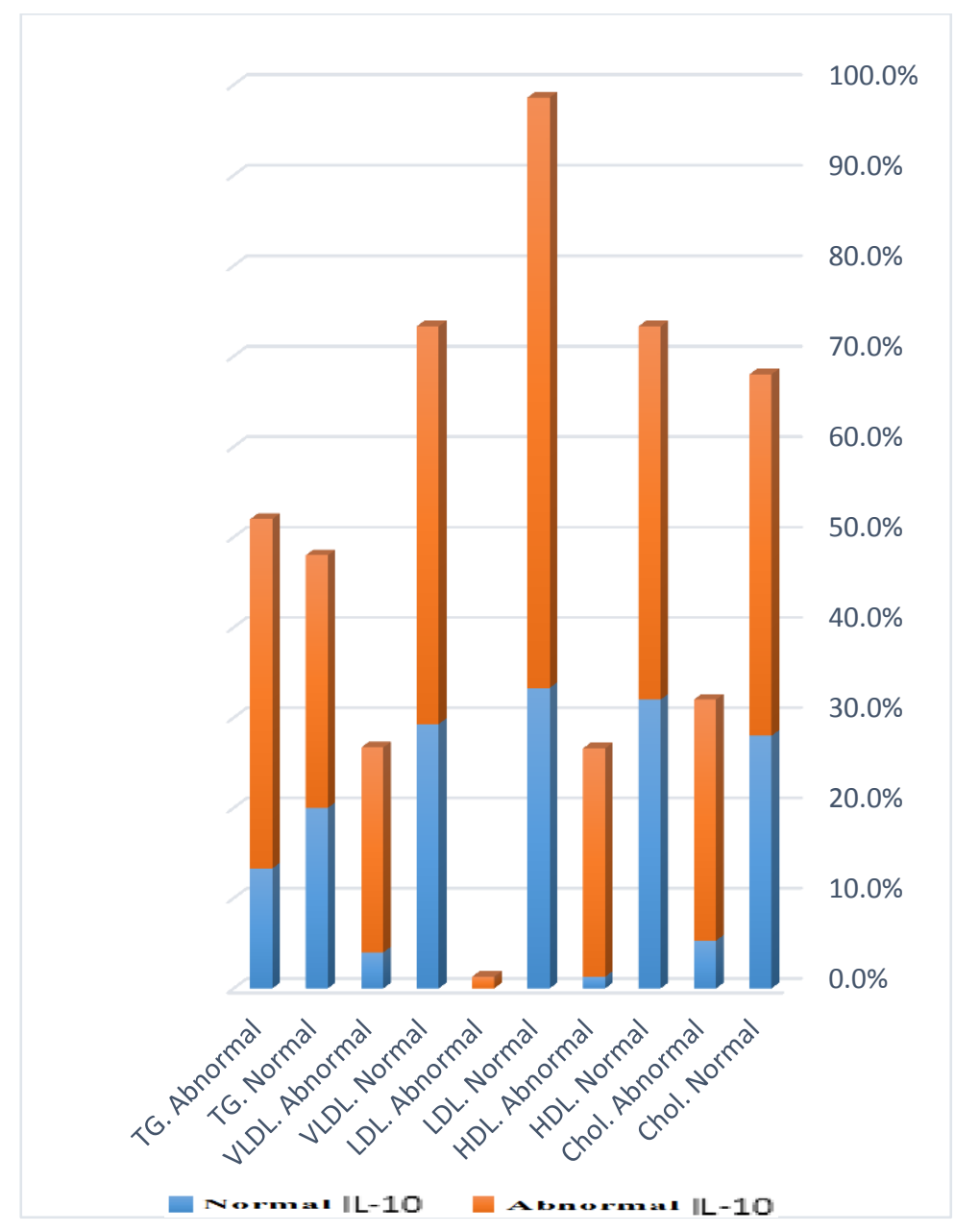

Figure(4): Distribution the levels of IL10 \& lipid profile in diabetic pateints. 


\section{4-Discussion}

Our result detected a high incidence of both types (I\& II) diabetes in age group 2 (41 -60) years. These results are contradictory with the results of Dabelea [9], who explained the incidence rate [one hundred thousand person/ year] of diabetes type 2 among adolescents and children that differs greatly by Ethnic origin, with maximum rates detected among the younger age group (15-19) years. Also a high prevalence of diabetes observed in female than male, and this result is similar to results of Marina, 2003 who showed that high rate of diabetes in female ( 57\% ) in comparison to male [10].

Results of current study showed an increase in levels of F.B.S; creatinine ;urea in type I diabetes than type II; which converge with Smyth's results, who explain that diabetic population was experiencing a mild kidney dysfunction, compared to controls (non-diabetic)[11].

The lipid profile(T-cholesterol ; triglyceride and both high and low density lipoprotein) levels were comparable in diabetic patients type II and control[12]; whilst Abouseif results showed a highest levels of lipid profil ( cholesterol ;HDL; LDL; VLDL and T.G) in type I diabetes rather type II diabetes and control [13].

During the acute phase response many changes occurred in lipid metabolism as a result, increased levels of serum triglycerides; but decreased levels of both (high and low density lipoprotein ) levels demonstrated by many studies [14].

Our result indicated that abnormal serum levels of IL-10 with biochemical tests , So Al-Mukhtar , 2005 explain the Serum total cholesterol (TC), low density lipoprote (LDL), and serum triglycerides (TG) were increased significantly $(\mathrm{P}>0.001)$ however, high density lipoprotein $(\mathrm{HDL})$ was decreased significantly $[\mathrm{P}<0.001)$ in diabetic patients as compared with controls, and conclude lipid profile was increased with advancement of diabetes mellitus[18], therefore biochemical tests can be used as a predictable risk factor for diabetes mellitus, also these results are similar with Van Exel ;who explained that there was a significant difference in IL-10 levels of diabetic patients (type II) in comparison to the healthy controls [15]. This suggests that these cytokines were contributed in immune pathogenesis of D.M [12].

Also our results showed that IL-10 serum level and lipid profile were abnormal, this can be explained by fact that IL-10 is a centrally, principal anti-inflammatory cytokine which has an important regulatory role for the innate immune system as well as, suppression for the production of various pro-inflammatory molecules [16], as well as, it may increase in response to the pro-inflammatory [17] ,So results of Nishida et al., Showed that cytokine (IL-10) Normal Valuely associated linking with D.M [19].

Also another study showed the levels of IL-10, Total cholesterol, triglycerides \&HDL levels were shown to be significantly, correlated diabetic patients but not in control group. In conclusion, low level of IL-10 could be involved in pathogenesis of type 2 diabetes and there is association between IL-10 and dyslipidemia in these patients[20].

\section{CONFLICT OF INTERESTS}

There are no conflicts of interest.

\section{References}

[1]Abou-Seif, M. A., \& Youssef, A.-A. 2004.Evaluation of some biochemical changes in diabetic patients. Clinica Chimica Acta, 346(2), 161-170, 2004.

[2]Powers Alvin C.2008. Diabetes mellitus. In: "Harrison, Brauwnwald, Kasper, editors. Harrison's Principles of Internal Medicine 17th ed." McGraw-Hill Companies, Inc; pp. 2275-2304.

[3]Graham, K. L., Sutherland, R. M., Mannering, S. I., Zhao, Y., Chee, J., Krishnamurthy, B., Kay, T. W. H. 2012.Pathogenic mechanisms in type 1 diabetes: the islet is both target and driver of disease. The Review of Diabetic Studies: RDS, 9(4), 148, 2012.

[4] Wu, Y., Ding, Y., Tanaka, Y., \& Zhang, W. 2014.Risk factors contributing to type 2 diabetes and recent advances in the treatment and prevention. International Journal of Medical Sciences, 11(11), 1185.

[5] Correa-Rotter, R., \& Gonzalez-Michaca, L. 2005.Early detection and prevention of diabetic nephropathy: a challenge calling for mandatory action for Mexico and the developing world. Kidney International, 68, S69-S75.

[6]Tektook, N. K. 2005.Bacteriological and Serological study in Diabetic patients with urinary tract infections and diabetic retinopathy. M.Sc. Thesis of Science in Biology. College of Science, University of Al-Mustansiriya, BaghdadIraq. 
[7]Menachem-Zidon, O. Ben, Avital, A., Ben-Menahem, Y., Goshen, I., Kreisel, T., Shmueli, E. M., Yirmiya, R.2011.Astrocytes support hippocampal-dependent memory and long-term potentiation via interleukin-1 signaling. Brain, Behavior, and Immunity, 25(5), 1008-1016.

[8]Marietta, E. V, Chen, Y., \& Weis, J. H. 1996.Modulation of expression of the anti-inflammatory cytokines interleukin-13 and interleukin-10 by interleukin-3. European Journal of Immunology, 26(1), 49-56.

[9]Dabelea, D., Bell, R. A., D’Agostino, J. R. B., Imperatore, G., Johansen, J. M., Linder, B., ... Mayer-Davis, E. J. 2007.Incidence of diabetes in youth in the United States. Jama, 297(24), 2716-2724.

[10]Scavini, M., Stidley, C. A., Shah, V. O., Narva, A. S., Tentori, F., Kessler, D. S., Jamon, E. 2003.Prevalence of diabetes is higher among female than male Zuni indians. Diabetes Care, 26(1), 55-60.

[11]Smyth, S., \& Heron, A. 2006.Diabetes and obesity: the twin epidemics”. Nature Medicine, 12(1), 75-80.

[12] Francisco, C. O., Catai, A. M., Moura-Tonello, S. C. G., Arruda, L. C. M., Lopes, S. L. B., Benze, B. G., Leal, A. M. O. 2016.Cytokine profile and lymphocyte subsets in type 2 diabetes. Brazilian Journal of Medical and Biological Research, 49(4): e5062.

[13] About diabetes.2014. World Health Organization. Archived from the original on 31 March 2014. Retrieved 4.

[14]Wattanasuwan, N., Khan, I. A., Gowda, R. M., Vasavada, B. C., \& Sacchi, T. J. .2001.Effect of acute myocardial infarction on cholesterol ratios. Chest, 120(4), 1196-1199.

[15]Van Exel, E., Gussekloo, J., de Craen, A. J. M., Frölich, M., Bootsma-van der Wiel, A., \& Westendorp, R. G. J. 2002.Low production capacity of interleukin-10 associates with the metabolic syndrome and type 2 diabetes": the Leiden 85-Plus Study. Diabetes, 51(4), 1088-1092.

[16]Biswas, S., Ghoshal, P. K., Mandal, S. C., \& Mandal, N. 2010.Relation of anti-to pro-inflammatory cytokine ratios with acute myocardial infarction. The Korean Journal of Internal Medicine, 25(1), 44-50.

[17]Lakoski, S. G., Liu, Y., Brosnihan, K. B., \& Herrington, D. M. 2008.Interleukin-10 concentration and coronary heart disease (CHD) event risk in the estrogen replacement and atherosclerosis (ERA) study. Atherosclerosis, 197(1), 443-447.
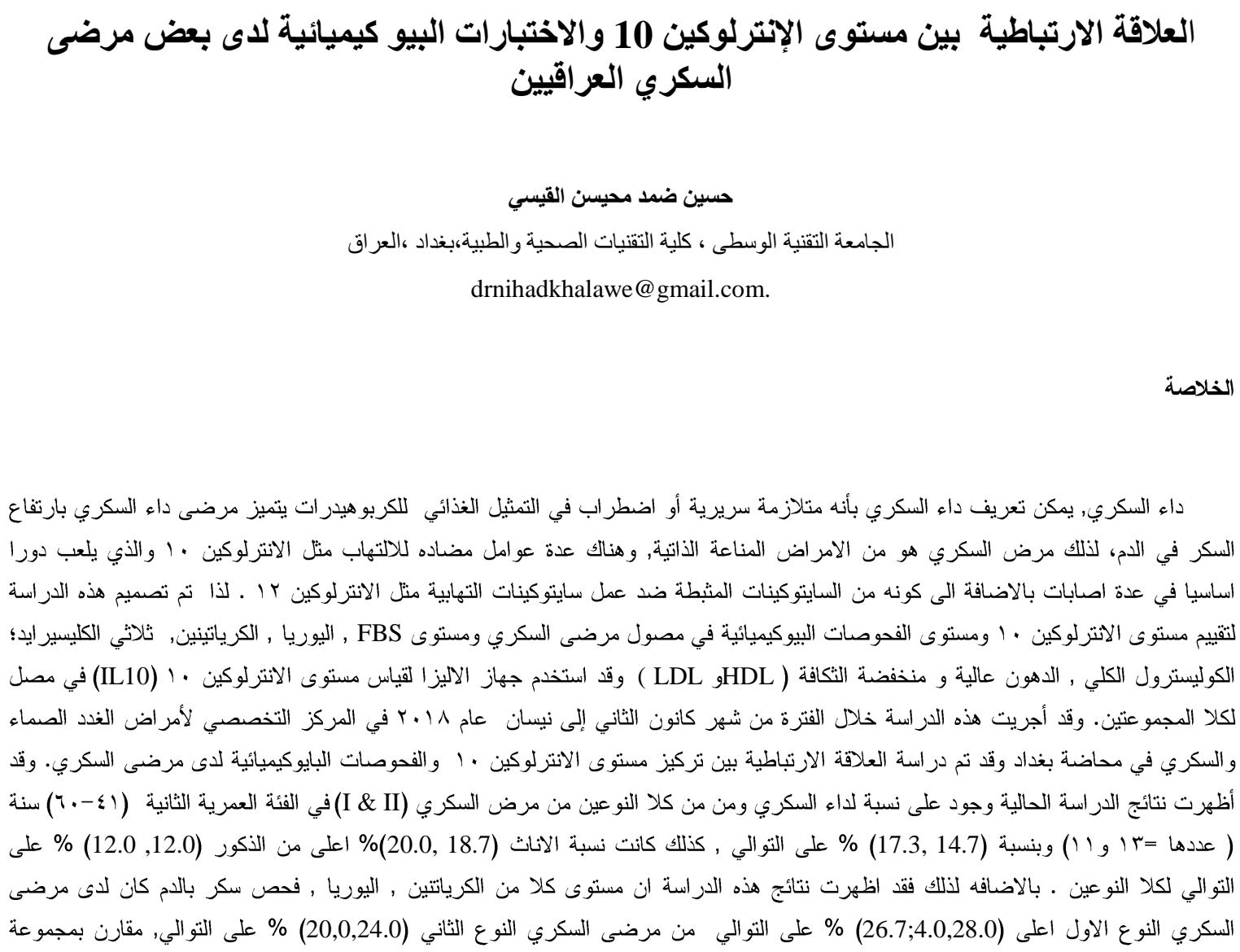


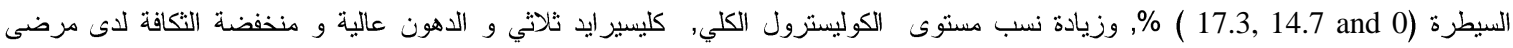

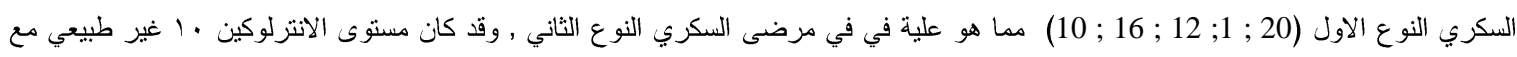

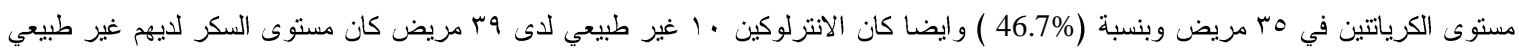

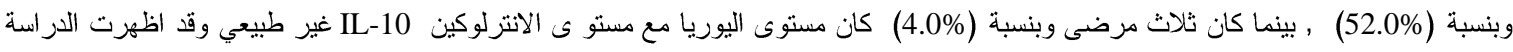

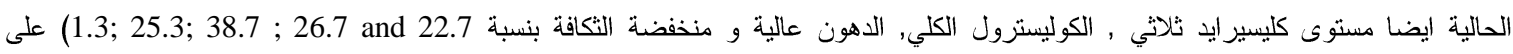

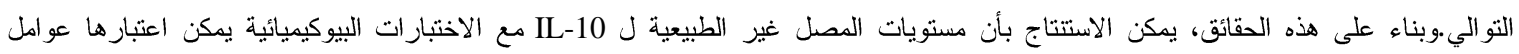

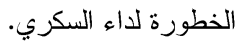
الكلمات الدالة: مرض السكري, الفحوصات البيوكيميائية, الانترلوكين, المرضى. 